\title{
Distance between parapatellar portal and intra-articular space for needle positioning in knee osteoarthritis
}

\author{
John Butarbutar, ${ }^{1}$ Yeremia Tatang, ${ }^{1}$ Hori Hariyanto, ${ }^{2}$ Edu Tehupeory, ${ }^{3}$ Ludwig A. Pontoh ${ }^{4}$ \\ ${ }^{1}$ Department of Surgery, Siloam Hospital, Pelita Harapan University, Jakarta, Indonesia \\ ${ }^{2}$ Department of Anesthesiology, Siloam Hospital, Pelita Harapan University, Jakarta, Indonesia \\ ${ }^{3}$ Department of Rheumatology, Faculty of Medicine, Hasanuddin University, Makassar, Indonesia \\ ${ }^{4}$ Department of Orthopaedy and Traumatology, Universitas Indonesia, Fatmawati Hospital, Jakarta, Indonesia
}

\begin{abstract}
Abstrak
Latar belakang: Injeksi intra-artikular merupakan prosedur terapi osteoartritis (OA) yang memerlukan tingkat akurasi tinggi. Penelitian ini bertujuan menentukan rerata jarak antara kulit dan rongga intra-artikular yang dapat digunakan sebagai panduan untuk memilih panjang jarum ketika melakukan injeksi intra-artikular pada pasien osteoartritis lutut.
\end{abstract}

\begin{abstract}
Metode: Dua puluh satu MRI lutut diambil dari 16 pasien wanita dengan osteoartritis lutut. Panjang jarum yang dibutuhkan untuk mencapai ruang intra-artikular didapatkan melalui rekonstruksi gambaran garis lurus dari kulit ke ruang intraartikular. Uji t berpasangan dipakai untuk melihat perbedaan mean hasil pengukuran bagian kiri dengan bagian kanan, dengan tingkat kemaknaan nilai $p<0,05$.

Hasil: Hasil menunjukkan tempat masuk dari parapatela pada medial dan lateral lebih kranial dari garis mid-patellar. Pada portal medial, jarak terdekat antara kulit dan cairan intra-artikular adalah 27,81 mm 7,58 mm. Jarak rerata titik portal adalah 4,46 2,16 mm kranial dari garis mid-patellar, dan 14,20 $\pm 4,45 \mathrm{~mm}$ posterior dari permukaan medial patela. Pada portal lateral, jarak terdekat dari kulit dan cairan intra-artikular adalah 16,84 $\pm 6,79 \mathrm{~mm}$. Jarak rata-rata titik injeksi adalah 11,10 $\pm 5,95 \mathrm{~mm}$ kranial dari garis mid-patellar, dan 8,91 $\pm 3,83 \mathrm{~mm}$ posterior dari permukaan lateral patela.
\end{abstract}

Kesimpulan: Studi MRI lutut menunjukkan bahwa rerata jarak antara kulit dan rongga intra-artikular lutut pada portal medial 27,81 \pm 7,58 mm sedangkan pada portal lateral 16,84 $\pm 6,79 \mathrm{~mm}$. Portal tersebut terletak kranial dari garis tengah patela dimana portal lateral lebih kranial dibandingkan medial, sehingga panjang jarum dan lokasi injeksi harus disesuaikan untuk meningkatkan akurasi injeksi intra-artikular. (Med J Indones. 2013;22:83-7)

\begin{abstract}
Background: Intra-articular injection is a common therapeutic procedure in osteoarthritis (OA) that need high accuracy. This study was aimed to measure the distance between parapatellar skin and intra-articular space as a guidance to choose the length of needle needed to perform intra-articular injection.

Methods: Twenty one knees MRI were taken from 16 females with knee osteoarthritis. The length of the needle needed to reach intra-articular space was reconstructed by drawing straight line from skin to intra-articular fluid. Paired t-test was using to analyze the mean difference of measurement of left side compare with right side with significant indicator if p-value $<0.05$.

Results: The entry point on both medial and lateral parapatellar were more cranial than transverse mid-patellar line. On medial portal, the closest distance from skin to intra-articular space is $27.81 \pm 7.58 \mathrm{~mm}$. Mean point of entry is $4.46 \pm 2.16 \mathrm{~mm}$ cranial to mid-patellar line, and $14.20 \pm 4.45 \mathrm{~mm}$ posterior to the prominence of medial border of patella. On lateral portal, the closest distance from skin to intra-articular space is $16.84 \pm 6.79 \mathrm{~mm}$. Mean point of entry is $11.10 \pm 5.94 \mathrm{~mm}$ cranial to mid-patellar line, and $8.91 \pm 3.83 \mathrm{~mm}$ posterior to the prominence of lateral border of patella.

Conclusion: MRI knee osteoarthritis study showed that the mean distance between skin and intra-articular joint space of medial portal is $27.81 \pm 7.58 \mathrm{~mm}$, and lateral portal is $16.84 \pm 6.79 \mathrm{~mm}$. The portals on both sides is cranial to midpoint of patella, lateral appears more proximal than medial. This should be put into consideration in choosing needle length and portal projection to increase intra-articular injection accuracy. (Med J Indones. 2013;22:83-7)
\end{abstract}

Keywords: Needle length, osteoarthritis, parapatellar skin portal

Intra-articular injection in osteoarthritis of the knee is common procedure nowadays. It can be done in outpatient setting, relatively simple procedure with the benefit of delivering drugs directly inside the joint. Many studies on pain control and disease modifying on the knees are using intra-articular injection as the method and variable portal of injection has been proposed, including superolateral, superomedial, anteromedial, anterolateral, lateral mid-patella, and medial mid-patella portal.

Some studies note the superiority of anterolateral (71$85 \%)$ and lateral mid-patella (76-93\%) in successfully enter the joint space. ${ }^{1,2}$ Anteromedial (73-75\%) and medial mid-patellar (56\%) show lower accuracy rate., ${ }^{1,3}$ Clearly this technical aspect would affect the results of 
those studies of intra-articular drugs. Intra-synovial and fat pad injections are also reported to be related with pain, bleeding into the joint, bruising, and nerve injury. ${ }^{4-6}$

To overcome the problem, some studies reports increase accuracy by using additional device and technique such as contrast with fluoroscopy and mini air technique which are either too complicated or expensive for daily practice. ${ }^{7-9}$ Injection on osteoarthritic knee could be different compare to normal knee due to changes in tibiofemoral and patella alignment, skin and soft tissue thickness in elderly and obese patients, and changes in synovium and fat pad patterns. ${ }^{10}$ This study is aimed to measure the distance between parapatellar skin and intra-articular space using MRI inpatients with knee osteoarthritis.

\section{METHODS}

\section{Subjects}

Sixteen females with knee osteoarthritis according to American College of Rheumatology were recruited from our ongoing study on Relationship Between Tibial Torsion and Degradation Process of Osteoarthritic Knee Joint in Menopausal Women. The research protocol has been approved by Ethical Committee of Universitas Hasanuddin. MRI scan with their knees in extension was done to 21 knees. Subjects with inflammatory joint disease were excluded.

\section{MRI examination}

This study was performed with 3 tesla MRI (Philips) using torso coil. A specially designed foot holder is used to immobilize the knee in upright position. Axial fat suppressed spin echo (FSE) proton density with a slice thickness $3 \mathrm{~mm}$ were obtained.

First, the skin entry point was determined, which represent the closest distance to intra-articular fluid. The length of the needle needed to reach intra-articular space was reconstructed by drawing straight line from skin to intra-articular space. We recorded minimum (min) and maximum distance ( $\max$ ) from skin to intraarticular fluid, the distance of the entry point below patellar bone prominence (post) and the entry point distance from mid-patellar line (sup). All distances were measured in millimeters ( $\mathrm{mm})$.

\section{Data analysis}

Data were analyzed by using paired t-test to look the mean difference of left side measurement compared with right side. The distance from both lateral and medial portal entry was measured and comparison between left and right, and correlation with Kellgren Lawrence (KL) grading and Body Mass Index (BMI) were analyzed. Kellgren Lawrence grading system was used to classify the narrowing of joint space: grade I-doubtful narrowing of joint space and possible osteophyticlipping; grade II -definite-osteophytes, definite narrowing of joint space; grade III -moderate-multiple osteophytes, definite narrowing of joints space, some sclerosis and possible deformity of bone contour; grade IV -large osteophytes, marked narrowing of joint space, severe sclerosis and definite deformity of bone contour.

\section{RESULTS}

Twenty one knees from 16 females with osteoarthritis had MRI scan with knees in extension.

Table 1. Individual data of age, BMI and KL score of study subjects

\begin{tabular}{ccccc}
\hline No & $\begin{array}{c}\text { Age } \\
\text { (years) }\end{array}$ & $\begin{array}{c}\text { BMI } \\
\left(\mathrm{kg} / \mathrm{m}^{2}\right)\end{array}$ & $\begin{array}{c}\text { KL } \\
\text { grading system }\end{array}$ & $\begin{array}{c}\text { Knees } \\
\text { (right/ left) }\end{array}$ \\
\hline 1 & 46 & 30.02 & II & R, L \\
2 & 65 & 24.32 & IV & R \\
3 & 75 & 26.91 & III & R, L \\
4 & 53 & 30.55 & II & R \\
5 & 58 & 28.89 & II & R, L \\
6 & 68 & 20.44 & II & R \\
7 & 61 & 26.91 & II & R, L \\
8 & 54 & 33.86 & II & L \\
9 & 66 & 25.97 & II & R \\
10 & 65 & 27.24 & III & R \\
11 & 64 & 27.24 & II & R, L \\
12 & 50 & 26.35 & II & R, L \\
13 & 46 & 28.30 & II & R, L \\
14 & 79 & 34.93 & IV & R \\
\hline
\end{tabular}

KL: Kelgren Lawrence; BMI: body mass index

Table 2. Patients distribution according to KL grade classification

\begin{tabular}{lcc}
\hline & Mean \pm SD & $\mathrm{n}(\%)$ \\
\hline Age (years) & $60.71 \pm 10.10$ & \\
KL grade II & & $16(76.2)$ \\
KL grade III & $3(14.3)$ \\
KL grade IV & $2(9.5)$ \\
BMI $\left(\mathrm{kg} / \mathrm{m}^{2}\right)$ & $27.99 \pm 3.67$ & \\
Side & & \\
$\quad$ Right & & $13(61.9)$ \\
\multicolumn{1}{c}{ Left } & & $8(38.1)$ \\
\hline
\end{tabular}

KL: Kelgren Lawrence; BMI: body mass index 
On medial portal, the closest distance from skin to intra-articular space was $27.81 \pm 7.58 \mathrm{~mm}$. The longest distance, from skin to intra-articular space before the line hit medial patellar facet was $45.15 \pm 9.81 \mathrm{~mm}$. Mean point of entry was $4.46 \pm 2.16 \mathrm{~mm}$ cranial to mid-patellar line, and $14.20 \pm 4.45 \mathrm{~mm}$ posterior to

Table 3. Measurement results of parapatellar distances from the skin to intra-articular fluid

\begin{tabular}{lccccc}
\hline & $\mathrm{n}$ & Minimum & Maximum & Mean & $\mathrm{SD}$ \\
\hline MP (min) & 20 & 15.60 & 42.60 & 27.81 & 7.57 \\
MP (max) & 20 & 30.60 & 65.20 & 45.14 & 9.81 \\
MP (sup) & 14 & 1.30 & 8.70 & 4.46 & 2.15 \\
MP (post) & 20 & 6.70 & 22.70 & 14.20 & 4.56 \\
LP (min) & 20 & 7.50 & 34.80 & 16.84 & 6.78 \\
LP (max) & 20 & 13.50 & 57.40 & 30.45 & 10.70 \\
LP (sup) & 19 & 2.10 & 24.10 & 11.10 & 5.94 \\
LP (post) & 20 & 2.80 & 17.40 & 8.90 & 3.82 \\
\hline
\end{tabular}

MP: medial parapatellar; LP: lateral parapatellar; (min): minimum distance from parapatellar skin to intra-articular fluid; (max): maximum distance from parapatellar skin to intra-articular fluid; (sup): distance between entry point and transverse mid-patellar line; (post): distance between entry point to patellar bony prominence. All distances were measured in millimeters $(\mathrm{mm})$ the prominence of medial border of patella. On lateral portal, the closest distance from skin to intra-articular space was $16.84 \pm 6.79 \mathrm{~mm}$. The longest distance from skin to intra-articular space was $30.46 \pm 10.71 \mathrm{~mm}$. Mean point of entry was $11.10 \pm 5.94 \mathrm{~mm}$ cranial to mid-patellar line, and $8.91 \pm 3.83 \mathrm{~mm}$ posterior to the prominence of lateral border of patella.

Data analysis shows that there were significant difference of portal measurement between right and left knees only in distance between point of entry and patellar prominence (parapatellar medial, $\mathrm{p}=0.011$; parapatellar lateral, $\mathrm{p}=0.031$ ). There was no significant difference in cranial and intra-articular depth between both sides.

Statistic shows that there were no correlation between BMI with medial parapatellar intra-articular space distances ([min], $\mathrm{p}=0.297 ;[\max ], \mathrm{p}=0.381$ ), cranial distance between entry point and transverse mid-patella $(p=0.176)$, and distance between entry pint and patellar prominence $(\mathrm{p}=0.553)$. There were also no correlation between BMI and lateral parapatellar intra-articular space distances ([min], $\mathrm{p}<0.381 ;[\max ], \mathrm{p}<0.381$ ), cranial distance between entry point and transverse midpatella $(\mathrm{p}<0.466)$, and distance between entry point and patellar prominence post $(\mathrm{p}<0.393)$.

Table 4. Paired t-test comparisons between left and right knee parapatellar distances

\begin{tabular}{lcccc}
\hline Variabel & $\mathrm{n}$ & Mean $\pm \mathrm{SD}$ & Min/Max & $\mathrm{p}$ \\
\hline MP ( min) right & 13 & $29.08 \pm 5.69$ & $20.8 / 36.5$ & 0.6046 \\
MP (min) left & 8 & $25.9 \pm 9.89$ & $15.6 / 42.6$ & \\
MP (max) right & 13 & $45.06 \pm 9.15$ & $30.6 / 64.5$ & 0.6832 \\
MP (max) left & 8 & $45.26 \pm 11.38$ & $32.5 / 65.2$ & \\
MP (sup) right & 13 & $2.57 \pm 2.67$ & $0 / 8.7$ & 0.1363 \\
MP (sup) left & 8 & $3.95 \pm 2.84$ & $0 / 7.2$ & \\
MP (post) right & 13 & $15.16 \pm 4.23$ & $6.7 / 22.7$ & 0.0107 \\
MP (post) left & 8 & $12.76 \pm 4.93$ & $6.7 / 20.9$ & \\
LP (min) right & 13 & $18.67 \pm 7.50$ & $7.5 / 34.8$ & 0.1682 \\
LP (min) left & 8 & $13.44 \pm 3.54$ & $10.1 / 19.4$ & \\
LP (max) right & 13 & $32.63 \pm 12.07$ & $13.5 / 57.4$ & \multirow{2}{*}{0.1207} \\
LP (max) left & 8 & $26.4 \pm 6.49$ & $18 / 34.3$ & \\
LP (sup) right & 13 & $11.31 \pm 7.28$ & $0 / 24.1$ & \multirow{2}{*}{0.7092} \\
LP (sup) left & 8 & $9.12 \pm 3.97$ & $2.1 / 15.2$ & \\
LP (post) right & 13 & $9.94 \pm 4.03$ & $5.1 / 17.4$ & 0.0313 \\
LP (post) left & 8 & $6.97 \pm 2.66$ & $2.8 / 10.3$ & \\
\hline MP: (medial pap & & & \\
\hline
\end{tabular}

MP: medial parapatellar; LP: lateral parapatellar; (min): minimum distance from parapatellar skin to intra-articular fluid; (max): maximum distance from parapatellar skin to intra-articular fluid; (sup): distance between entry point and transverse mid-patellar line; (post): distance between entry point to patellar bony prominence. All distances were measured in millimeters ( $\mathrm{mm}$ ) 

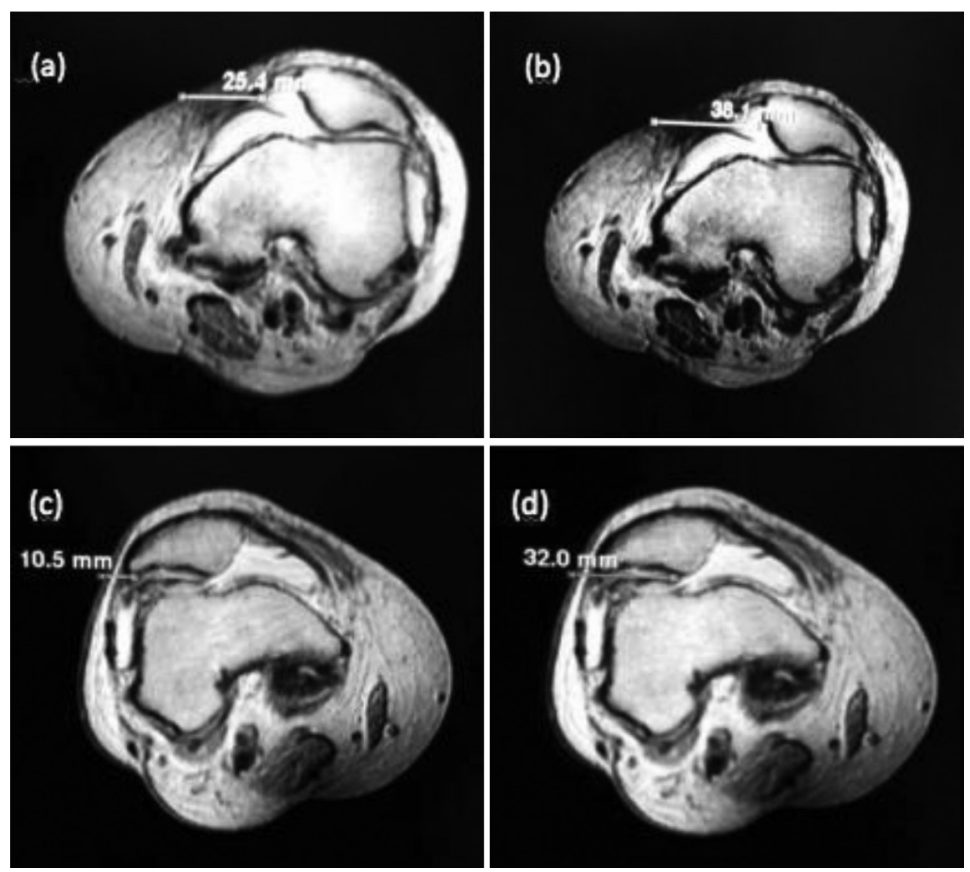

Figure 1. MRI imaging on medial and lateral portals: Minimal (a) and maximal (b) distance between parapatelar lateral skin portal and joint space; minimal (c) and maximal (d) distance between parapatellar medial skin portal and joint space

There were no correlation found between KL grade and distances entry point and medial intra-articular space ([min], $\mathrm{p}=0.368 ;[\max ], \mathrm{p}<0.368)$, cranial distance between entry point and transverse midpatella $(\mathrm{p}<0.240)$, distance between entry point and patellar prominence $(p<0.267)$. There were also no correlation found between KL grade and distances entry point and lateral intra-articular space ([min], $p$ $=0.267 ;[\max ], \mathrm{p}<0.368)$, cranial distance between entry point and transverse mid-patella $(\mathrm{p}=0.176)$, distance between entry point and patellar prominence $(\mathrm{p}<0.658)$.

\section{DISCUSSION}

Knee joint was thought to be the easiest joint to inject since it is located superficially and has relatively large intra-articular space. However several studies showed different and sometimes low accuracy of knee intra-articular injection that also depend on different injection portal used by investigators. ${ }^{1,3,6}$

Most of knee intra-articular injection nowadays were done on osteoarthritic condition with no inflammation, where minimal intra-articular fluid combine with bony deformity and malalignment could possibly lower the accuracy of putting the needle into intraarticular space. That's why it is important to improve our understanding on knee injection portal in osteoarthritic knee.
Good portal would be one which could provide short distance between skin and intra-articular, big joint space, far from sensitive structures, less dependent on joint fluid fluctuation and knee deformity, and easily define using surrounding landmark.

MRI was used in this study since it is capable to depict intra-articular fluid which represent dynamic intra-articular potential space and also able to do measurement of its distance to surrounding soft tissue structures.

Bony prominence is used in this study as landmark of measurement, because in our opinion, it is more readily define in clinical setting compare to upper and lower pole of patella that are located inside quadriceps tendon and patellar ligament.

According to our result, point of entry on both medial and lateral parapatellar should be more cranial than midpoint of patella, because of lack joint fluid on the level of transverse line of mid-patella and frequent potential obstruction from patellofemoral osteophytes. Accordingly, the term lateral and medial mid-patellar portal for knee injection are not appropriate and could be misleading.

On several images, medial parapatellar plicas are getting the way between medial skin entry point and joint space This may explain some double resistance during intra-articular injection using medial portal. 
The direction of the lateral facet patellar cartilage surface is almost horizontal and the direction medial facet patella is about 45 degrees tilt. Caution should be taken in directing angle of needle during insertion to minimize risk of hitting joint cartilage.

Clinician tends to use needle with smallest diameter possible for patients comfort. Based on our results, 1.5 inch needle is appropriate for medial portal and 1 inch needle for lateral portal. However, the closest distance from skin to patellar articular surface is $35.34 \mathrm{~mm}$ (45.15 mm - SD 9.81) in medial portal and $19.7 \mathrm{~mm}$ (30.46 mm - SD 10.71) in lateral portal. Therefore, the clinician should insert the needle deep enough only to penetrate joint capsule. Inserting the whole length of the needle has possible risk of damaging cartilage.

In this study, we found significant difference between right and left knee on distance between entry point and patellar prominence border. It could be results of different patellar tilt between both sides. Identifying parapatellar soft spot posterior to patella will help to identify this variation. No significant influence of BMI and KL grade to parapatellar portal point of entry showed independent character of this portal and was a benefit for clinician.

Several consideration should be taken due to study's weakness. Small sample population with only one gender (female) may not represent general knee OA population. Patellar manipulation during injection procedure to open the joint space and stretch the capsule is also cannot be reconstructed in this study because it is so variable depending on physician preference, although we believe that our result could still be applicable as a baseline for physician to predict the consequences of his manipulation to patella in directing the needle.

In conclusion, despite a fact as the most common intraarticular procedure, knee injection studies still result in variable accuracy with lack description of portal site and needle direction. Our MRI study shows that joint space fluid on both sides was cranial to midpoint of patella, lateral side appears more cranial than medial side, and needle projection should be directed accordingly to increase intra-articular injection accuracy.

\section{REFERENCES}

1. Jackson DW, Evans NA, Thomas BM. Accuracy of needle placement into the intra-articular space of the knee. J Bone Joint Surg Am. 2002; 84-A(9):1522-7.

2. Lavelle M, Lavelle ED, Lavelle L. Intra-articular injections. Anesthesiol Clin. 2007;25(4):853-62.

3. Esenyel C, Demirhan M, Esenyel M, et al. Comparison of four different intra-articular injection sites in the knee: a cadaver study. Knee Surg Sports Traumatol Arthrosc. 2007;15(5):573-7.

4. Lussier A, Cividino AA, McFarlane CA, Olszynski WP, Potashner WJ, De Medicis R. Viscosupplementation with hylan for the treatment of osteoarthritis: findings from clinical practice in Canada. J Rheumatol. 1996;23(9):1579-85.

5. Sharma L, Song J, Felson DT, Cahue S, Shamiyeh E, Dunlop DD. The role of knee alignment in disease progression and functional decline in knee osteoarthritis. JAMA. 2001;286(2):188-95.

6. Jones A, Regan M, Ledingham J, Pattrick M, Manhire A, Doherty M. Importance of placement intra-articular steroid injections. BMJ. 1993;307:1329-30.

7. Bliddal H. Placement of intra-articular injections verified by mini-air arthrography. Ann Rheum Dis. 1999;58(10):641-3.

8. Waddell D, Estey D, Bricker DC, Marsala A. Viscosupplementation under fluoroscopic control. Am J Med Sports. 2001;3:237-41.

9. Masala S, Fiori R, Bartolucci DA, et al. Diagnostic and therapeutic joint injections. Semin Intervent Radiol. 2010; 27(2):160-71.

10. Gaffney $\mathrm{K}$, Ledingham J, Perry J D. Intra-articular triamcinolone hexacetonide in knee osteoarthritis: factors influencing the clinical response. Anneheum Dis. 1995;54(5):379-81. 